\title{
Cropping pattern optimization considering uncertainty of water availability and water saving potential
}

\author{
Lina $\mathrm{Hao}^{1}$, Xiaoling $\mathrm{Su}^{1 *}$, Vijay P. Singh ${ }^{2}$ \\ (1. College of Water Resources and Architectural Engineering, Northwest A\& F University, Yangling 712100, Shaanxi, China; \\ 2. Department of Biological \& Agricultural Engineering and Zachry Department of Civil Engineering, Texas A\&M University, \\ College Station, TX 77843-2117, USA)
}

\begin{abstract}
In arid and semi-arid areas, the profitability of irrigated agriculture mainly depends on the availability of water resources and optimal cropping patterns of irrigation districts. In this study, an integrated agricultural cropping pattern optimization model was developed with considering the uncertainty of water availability and water saving potential in the future, aiming to maximize agricultural net benefit per unit of irrigation water. The available water which was based on the uncertainty of runoff was divided into five scenarios. The irrigation water-saving potential in the future was quantified by assuming an increase in the rate irrigation water-saving of $10 \%$ and $20 \%$. The model was applied to the middle reaches of Heihe River basin, in Gansu Province, China. Results showed that if the irrigation water-saving rate was assumed to increase by $10 \%$, then the net water-saving quantity would increase by $21.5-22.5$ million $\mathrm{m}^{3}$ and the gross water-saving quantity would increase by 275.7-303.0 million $\mathrm{m}^{3}$. Similarly, if the irrigation water-saving rate increased by $20 \%$, then the net water-saving quantity would increase by 43.0-45.1 million $\mathrm{m}^{3}$ and the gross water-saving quantity would increase by $331.7-383.2 \mathrm{million}^{3}$. If the agricultural cropping pattern was optimized, the optimal water and cultivated area allocation for maize would be greater than those for other crops. Under the premise that similar volume of irrigation water quantity was available in different scenarios, results showed differences in system benefit and net benefit per unit of irrigation water, for the distribution of available irrigation water was diverse in different irrigation districts.
\end{abstract}

Keywords: cropping pattern optimization, irrigation water-saving potential, different scenarios, water availability, water use efficiency, particle swarm optimization (PSO)

DOI: $10.25165 /$ j.ijabe. 20181101.3658

Citation: Hao L N, Su X L, Singh V P. Cropping pattern optimization considering uncertainty of water availability and water saving potential. Int J Agric \& Biol Eng, 2018; 11(1): 178-186.

\section{Introduction}

Optimization of cropping patterns plays an important role in high-benefit and water-saving agricultural management ${ }^{[1]}$, which determines the water requirement at the head and ultimately helps estimate the required capacity of the reservoir and the canal system $^{[2]}$. In arid and semi-arid areas, the profitability of irrigated agriculture mainly depends on the availability of irrigation water and the cropping pattern of irrigation districts. Irrigation water is a key determinant of a crop area optimization model ${ }^{[3]}$. However, waste of irrigation water, owing to the lower use efficiency, has made aggravated the crisis of irrigation water ${ }^{[4,5]}$. At present time in northwest of China, irrigation efficiency is low, meaning there is higher agriculture water-saving potential ${ }^{[6]}$. In order to alleviate water shortage for irrigation, it is therefore essential to develop water-saving irrigation. Estimation of irrigation water-saving potential, which can calculate how much water could be saved by adopting water-saving measures, is desired and would benefit

\section{Received date: 2017-07-22 Accepted date: 2017-11-28}

Biographies: Lina Hao, PhD candidate, research interests: optimal allocation of water resources, Email: haolina@nwafu.edu.cn; Vijay P. Singh, Professor, research interests: hydrology and hydraulics, Email: vsingh@tamu.edu.

*Corresponding author: Xiaoling Su, Professor, research interests: optimal allocation of water resources, water conversion and regulation of water resources, College of Water Resources and Architectural Engineering, Northwest A\&F University, No.23 Weihui Rd, Yangling 712100, Shaanxi, China. Tel: +8613892816132, Email: xiaolingsu@nwsuaf.edu.cn. agricultural water management ${ }^{[7,8]}$. Many studies have investigated water-saving potential ${ }^{[6,9,10]}$. Jägermeyr et al. $^{[11]}$ incorporated a process-based irrigation system representation $\mathrm{n}$ into a bio-agrosphere model to calculate the water saving potential. Yan et al. ${ }^{[12]}$ investigated on-farm techniques to assess water consumption of some crops. Gao et al. ${ }^{[13]}$ applied user's preference for saving water and adopting end use analysis to analyze water conservation. Damerau et al. ${ }^{[14]}$ estimated water saving potential from the viewpoint of development of future food and energy supply. However, previous literature focused on applying experimental and statistical methods to quantify agricultural water saving potential but relatively little attention was given to the irrigation water-saving potential caused by agricultural water-saving engineering development.

An optimal cropping pattern depends upon the water availability, with the objective of meeting the maximum irrigation potential as well as the maximum economic return ${ }^{[2]}$. Mathematical models, such as linear programming ${ }^{[15-17]}$ and non-linear programming ${ }^{[7,18-20]}$, have been widely used for achieving different objectives. For cropping pattern optimization, different optimization objectives, such as single objective ${ }^{[21]}$ or multi objectives ${ }^{[22,23]}$ need to be considered for the decision maker. For a multi objective model, mathematical techniques that can handle all the objectives simultaneously are needed. Examples of such mathematical techniques include goal programming ${ }^{[24,25]}$, fuzzy optimization ${ }^{[26-28]}$, and stochastic optimization ${ }^{[29-31]}$.

Numerous factors can influence the results of cropping pattern optimization. Some researchers have studied cropping pattern 
optimization considering the influence of these factors. For example, Zhang and Guo ${ }^{[8]}$ obtained optimal solutions of planting structure by adjusting planting scale and multiple cropping indexes to determine the rule of water saving quantity-benefit. Cid-Garcia et al. ${ }^{[32]}$ determined an optimal crop pattern for maximizing the farmer's expected profit by assessing the chemical and physical management zones. Dong et al. ${ }^{[4]}$ combined the vulnerability and contribution rate assessment to propose an effective solution for crop structure adjustment.

However, incorporating the irrigation water-saving potential in cropping pattern optimization does not seem to have been investigated. Therefore, it would be desirable to develop a model that can handle uncertainties and complexities in cropping pattern optimization, with the aim to maximize profitability of irrigation water. This paper focuses on the irrigation water-saving potential, estimating how much water could be saved and reused in an irrigation system through the development of water-saving agriculture in future. Therefore this paper proposed a development pattern of agricultural crops in the future, based on agricultural cropping pattern optimization model considering different hydrological frequencies, and in conjunction with agricultural irrigation water-saving potential in future.

\section{Materials and methods}

\subsection{Study area}

The study area is located in the middle reaches of Heihe River basin $\left(97^{\circ} 37^{\prime}-102^{\circ} 06^{\prime} \mathrm{E}, 37^{\circ} 44^{\prime}-42^{\circ} 40^{\prime} \mathrm{N}\right)$, northwest of China. In the arid and semi-arid areas, crop growth mainly depends on agricultural irrigation. Thus, agricultural available water should be taken into consideration, when making decision for suitable and sustainable cultivated land scale ${ }^{[34]}$. However, it is estimated that the water use efficiency of agricultural irrigation in the middle reaches merely approaches to $0.52^{[3,5]}$. This suggests that there is high agricultural water-saving potential. Improving the efficiency of irrigation water use thus becomes the effective way to improve agricultural benefit ${ }^{[36]}$. Hence there is enormous potential to improve agricultural water resources. Therefore, estimating irrigation water-saving potential, which can calculate how much water could be saved by adopting water-saving measures, is desired and would benefit water-saving agricultural development.

The study area includes 17 irrigation districts in Ganzhou District, Linze County and Gaotai County (as shown in Figure 1).

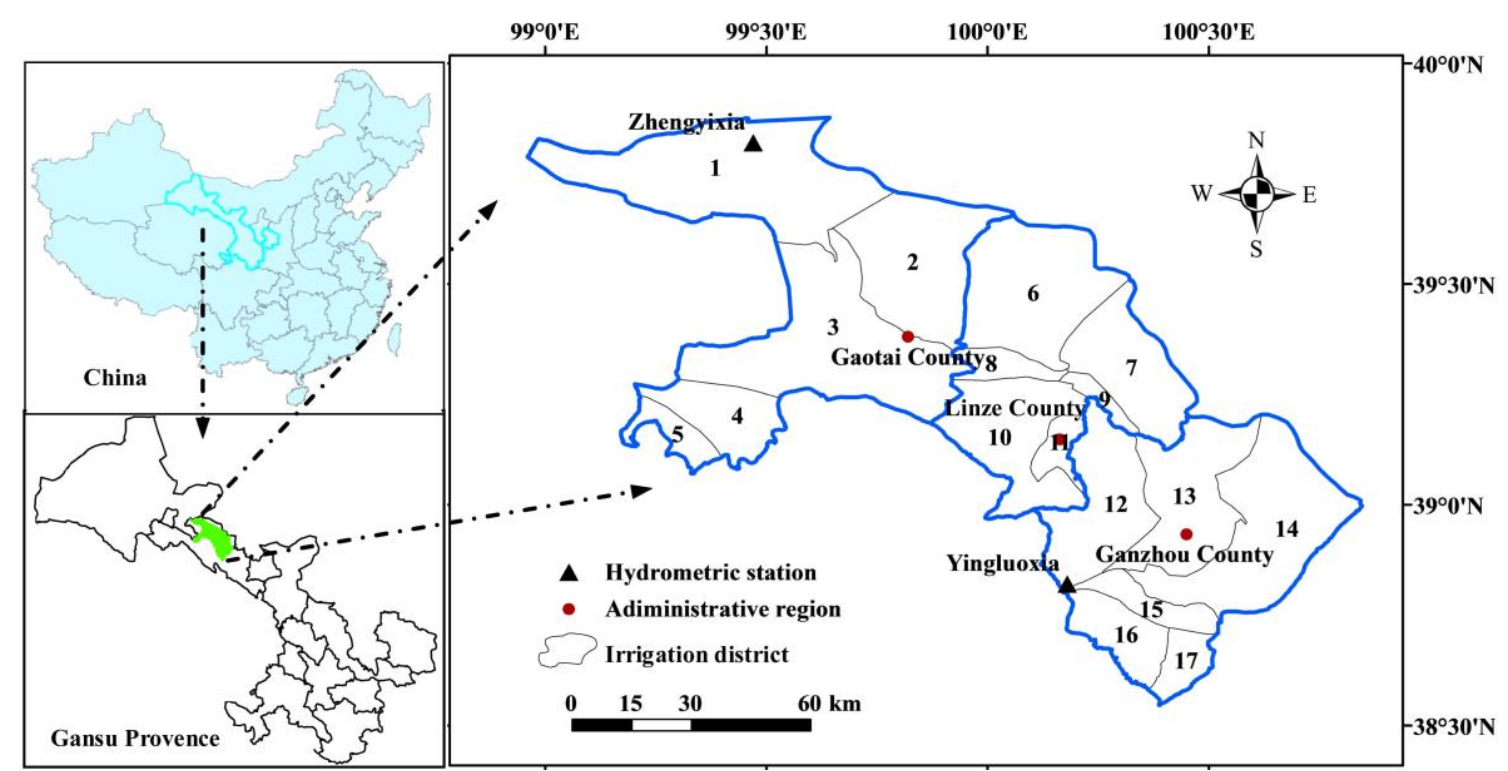

1. Luocheng irrigation district (LC) 2. Liuba irrigation district (LB) 3. Youlian irrigation district (YL) 4. Xinba irrigation district (XB) 5. Hongyazi irrigation district (HYZ) 6. Pingchuan irrigation district (PC) 7. Banqiao irrigation district (BQ) 8. Liaoquan irrigation district (LQ) 9. Yanuan irrigation district (YN) 10. Liyuanhe irrigation district $(\mathrm{LYH}) \quad$ 11. Shahe irrigation district $(\mathrm{SH})$ 12. Xijun irrigation district (XJ) 13. Yingke irrigation district (YK) 14. Daman irrigation district (DM) 15. Shangshan irrigation district (SS) 16. Huazhai irrigation district (HZ) 17. Anyang irrigation district (AY)

Figure 1 Study system of the middle reaches of Heihe River basin

\subsection{Methods and data}

\subsubsection{Data acquisition}

Data related to water-saving condition (water-saving area, irrigation quota in water-saving condition) were collected through Zhangye Irrigation Management Report (http://swj.zhangye. gov.cn/). Parameters related to irrigation quota, crop yield, the net irrigation quota of crop, cost and price of 7 crops were collected through the Statistical Yearbook of Zhangye City (http://www.zytj.gov.cn/). Agricultural price data were obtained from the Gansu prices net (http://www.gswj.gov.cn/). Annual minimum grain and vegetable demand were according to China Food and Nutrition Development Outline (http://www.moa. gov.cn/). Available irrigation water under different probabilities of water level in irrigation districts (as shown in Table 1) was obtained from Zhao et al. ${ }^{[38]}$

The category of five flow year was based on the frequency analysis method ${ }^{[38]}$. Let $p$ denotes the hydrological frequencies, the flow years divided into five conditions of very-high, high, middle-level, low and very low with $p \leq 12.5 \%, 12.5 \%<p \leq 37.5 \%$, $37.5 \%<p \leq 62.5 \%, 62.5 \%<p \leq 87.5 \%$ and $87.5 \%<p$, respectively.

2.2.2 Irrigation water-saving potential

In order to explore agricultural water-saving potential by adopting efficient agricultural water management inside an agriculture irrigation system, this study quantified agricultural water-saving potential by distinguishing "net water saving" and "gross water saving" based on irrigation water-saving potential estimation theory ${ }^{[6]}$ at the irrigation district scale under different proportions of an agricultural water-saving irrigation area. According to this theory, the concepts "gross water saving" and "net water saving" were introduced to avoid the argument between engineering-type water-saving and real water-saving. Gross water saving is the quantity of irrigation water saving on account of 
improving the efficiency of irrigation water use and reducing seepage loss and soil evaporation. The net water saving is the quantity of saving of invalid water consumption and invalid loss water $^{[6]}$

Table 1 Available irrigation water under different hydrological frequencies in irrigation districts million $\mathrm{m}^{3}$

\begin{tabular}{|c|c|c|c|c|c|c|c|}
\hline Administrative region & \multicolumn{2}{|c|}{ Irrigation districts } & Very-low years & Low years & Middle-level years & High years & Very-high years \\
\hline \multirow{6}{*}{ Gaotai County } & 1 & $\mathrm{LC}$ & 36.14 & 36.05 & 35.82 & 35.72 & 35.64 \\
\hline & 2 & LB & 23.75 & 23.62 & 23.85 & 24.00 & 23.99 \\
\hline & 3 & YL & 253.31 & 241.87 & 236.00 & 231.94 & 230.81 \\
\hline & 4 & $\mathrm{XB}$ & 44.88 & 44.88 & 44.88 & 44.88 & 44.88 \\
\hline & 5 & HYZ & 22.03 & 22.03 & 22.03 & 22.03 & 22.03 \\
\hline & 6 & $\mathrm{PC}$ & 73.99 & 71.81 & 68.89 & 66.76 & 66.81 \\
\hline \multirow{5}{*}{ Linze County } & 7 & BQ & 89.96 & 76.15 & 71.62 & 66.87 & 66.98 \\
\hline & 8 & LQ & 33.82 & 33.81 & 33.12 & 32.87 & 32.89 \\
\hline & 9 & YN & 21.93 & 22.02 & 21.92 & 21.95 & 21.95 \\
\hline & 10 & LYH & 49.99 & 166.85 & 166.85 & 166.85 & 166.85 \\
\hline & 11 & $\mathrm{SH}$ & 39.34 & 34.56 & 32.90 & 31.66 & 33.44 \\
\hline \multirow{6}{*}{ Ganzhou District } & 12 & $\mathrm{XJ}$ & 234.21 & 224.93 & 216.94 & 211.95 & 221.52 \\
\hline & 13 & YK & 201.31 & 194.40 & 187.64 & 183.43 & 191.54 \\
\hline & 14 & DM & 169.35 & 168.92 & 164.12 & 161.18 & 167.03 \\
\hline & 15 & SS & 86.43 & 75.94 & 72.05 & 68.71 & 73.40 \\
\hline & 16 & $\mathrm{HZ}$ & 7.30 & 7.30 & 7.30 & 7.30 & 7.30 \\
\hline & 17 & AY & 26.68 & 26.68 & 26.68 & 26.68 & 26.68 \\
\hline Sum & & & 1414.43 & 1471.82 & 1432.61 & 1404.77 & 1433.73 \\
\hline
\end{tabular}

Figure 2 illustrates a detailed decomposition of gross water saving and net water saving. Gross water saving mainly includes two parts, one is invalid water loss reduced and the other is invalid water consumption reduced.

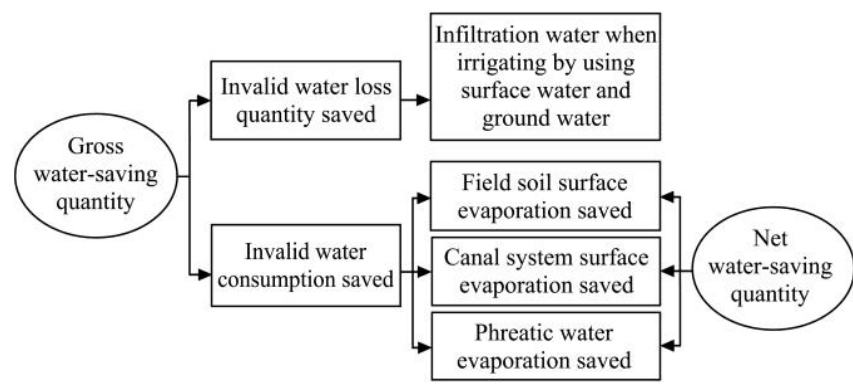

Figure 2 Components of gross water-saving quantity and net water-saving quantity ${ }^{[6]}$

Gross water saving gives an account of engineering-type water-saving potential, which is the water saved in irrigation canal systems, field irrigation systems and management of water saving irrigation project. In other words, gross water saving is the amount of irrigation water saving on account of improving the efficiency of irrigation water use, which gives an account of the difference in value between irrigation water availability at the present time and water saving scenarios in future. According to the irrigation water-saving potential estimation theory established by Lei et al. ${ }^{[6]}$, net water-saving quantity and gross water-saving quantity can be expressed as below.

(1) Net water-saving quantity

The net water-saving quantity is defined as the saving quantity of invalid water consumption, expressed as Equation (1):

$$
\Delta W_{n e t}=\sum_{1}^{n} \Delta A_{i} \cdot \Delta I_{i}
$$

where, $\Delta W_{\text {net }}$ is the net water-saving quantity; $\Delta A_{i}$ is the increasing area of water-saving measure $i$; and $\Delta I_{i}$ is the reduction of net irrigation quota of water-saving measure $i$.
(2) Gross water-saving quantity

Gross water-saving is the amount of water-saving on account of improving the efficiency of irrigation water use and reducing seepage loss and soil evaporation, expressed as Equation (2):

$$
\Delta W_{\text {gross }}=W_{0}-W_{t}=A_{0}\left(\frac{I_{\text {net } 0}}{\eta_{0}}-\frac{I_{\text {nett }}}{\eta_{t}}\right)
$$

where, $\Delta W_{\text {gross }}$ is the gross water-saving quantity; $W_{0}$ is the irrigation water in the status quo condition; $W_{t}$ is the irrigation water in the water-saving condition; $A_{0}$ is the irrigation area; $I_{n e t 0}$ is the net irrigation quota in the status quo condition; $I_{\text {nett }}$ is the net irrigation quota in the water-saving condition; $\eta_{0}$ is the efficiency of water use in irrigation systems in the status quo condition; $\eta_{t}$ is the efficiency of water use in irrigation systems in the water-saving condition. Here $I_{\text {net } 0}$ can be formulated as Equation (3), $I_{\text {nett }}$ can be formulated as Equation (4), $\eta_{t}$ can be formulated as Equation (5), $\eta_{i}$ denotes the efficiency of water use of water-saving measure $i$.

$$
\begin{gathered}
I_{\text {net } 0}=\frac{W_{0} \cdot \eta_{0}}{A_{0}} \\
I_{\text {nett }}=\frac{A_{0} \cdot I_{\text {net } 0}-\sum_{i}^{n}\left(\Delta A_{i} \cdot \Delta I_{i}\right)}{A_{0}}=I_{\text {net } 0}-\frac{\Delta W_{\text {net }}}{A_{0}} \\
\eta_{t}=\frac{\sum_{i=1}^{n}\left(A_{i} \cdot \eta_{i}\right)}{A_{0}}
\end{gathered}
$$

2.2.3 Crop structure optimization model based on irrigation water-saving potential

In this study, an integrated agricultural cropping pattern optimization model is built, based on the present agricultural crop development pattern, in conjunction with agricultural water saving potential in the future to gain high-efficiency water management solutions. The question under consideration is quantifying agricultural water saving potential and how to determine the optimal structure which could obtain maximum agricultural net benefit per unit of irrigation water by allocating the limited water to 
seven main crops (maize, wheat, potato, maize seed, cotton, oil crops, and vegetables), which is in the pursuit of the maximum water use efficiency. The objective function of integrated agricultural cropping pattern optimization model can be expressed as follow equations:

$$
\max f=\sum_{i=1}^{n} \sum_{j=1}^{7}\left(\left(y_{i j} v_{i j}-c_{i j}\right) \cdot x_{i j} / E T_{i j}\right) / \sum_{i=1}^{n} \sum_{j=1}^{7} x_{i j}
$$

where, $f$ is the expected net benefit per unit of irrigation water $\left(\mathrm{RMB} / \mathrm{m}^{3}\right) ; i(i=1,2, \cdots, 17)$ is subarea, the meaning has been illustrated in Table $1 ; j(j=1,2, \cdots, 7)$ is the crop type, with $j=1$ means maize, $j=2$ wheat, $j=3$ means potato, $j=4$ means maize seed, $j=5$ means cotton, $j=6$ means oil crops, $j=7$ means vegetables; $x_{i j}$ is decision variable, which expresses the planting area of crop $j$ on irrigation district $i$ (ha); $y_{i j}$ is the yield per unit area of crop $j$ in the irrigation district $i(\mathrm{~kg} / \mathrm{ha}) ; c_{i j}$ is the cost of crop $j$ in the irrigation district $i(\mathrm{RMB} / \mathrm{ha})$; and $E T_{i j}$ is the net irrigation quota of crop $j$ in the irrigation district $i\left(\mathrm{~m}^{3} / \mathrm{hm}^{2}\right)$.

Subject to the following constraints:

Water supply to irrigation district would be less than the available water:

$$
\sum_{i=1}^{n} \sum_{j=1}^{7} m_{i j} x_{i j} \leq Q_{i}+\Delta W_{\text {gross } i}
$$

The crop area would be less then the irrigation district area:

$$
\sum_{i=1}^{n} \sum_{j=1}^{7} x_{i j} \leq X_{n}
$$

Agricultural product (crop and vegetable) would be to meet the local demand:

$$
\begin{gathered}
\sum_{i=1}^{n} \sum_{j=1}^{4} x_{i j} \cdot y_{i j} \geq K \cdot P \cdot F N \\
\sum_{i=1}^{n} \sum_{j=9} x_{i j} \cdot y_{i j} \geq K \cdot P \cdot V N \\
x_{i j} \geq 0
\end{gathered}
$$

where, $m_{i j}$ is the gross irrigation quota of crop $j$ in the irrigation district $i\left(\mathrm{~m}^{3} / \mathrm{hm}^{2}\right) ; Q_{i}$ is the available water supply in the irrigation district $i\left(\mathrm{~m}^{3}\right) ; \Delta W_{\text {gross } i}$ is the gross water-saving quantity in the irrigation district $i\left(\mathrm{~m}^{3}\right) ; X_{n}$ is the effective irrigated area of the irrigation district $i\left(\mathrm{hm}^{2}\right) ; P$ is the population in the study area; $F N$ is the per person grain demand, $135 \mathrm{~kg} /$ person; and $V N$ is the per person vegetable demand, $140 \mathrm{~kg} /$ person.

\subsubsection{Particle swarm optimization}

There are a large number of variables in the agricultural cropping pattern optimization model. Particle swarm optimization (PSO) is an effective alternative for dealing with multiple variables which is stochastic population-based algorithm motivated by intelligent collective behavior of birds.

In PSO, an individual is compared to a particle and the population is called as a swarm ${ }^{[33]}$. The particle moves in a search space by updating velocity and position which represent the possible way to the problem and the direction to obtain the global optimal value. The position and velocity can be upgraded by formulas (12) and (13):

$$
v_{i}(t+1)=\omega(t) \cdot v_{i}(t)+c_{1} \cdot r_{1} \cdot\left(P_{i}(t)-x_{i}(t)\right)+c_{2} \cdot r_{2} \cdot\left(P_{\mathrm{g}}(t)-x_{i}(t)\right)
$$

$$
x_{i}(t+1)=x_{i}(t)+r \cdot v_{i}(t+1)
$$

where, $v_{i}(t)$ and $x_{i}(t)$ are the velocity and position of particle $i$ at iteration $t ; P_{i}(t)$ is the position with the best fitness value; $P_{\mathrm{g}}(t)$ is the global best position; $c_{1}$ and $c_{2}$ are positive constant parameters which are called acceleration coefficients, and are usually assigned a value $1 ; r_{1}, r_{2}$ are random numbers between 0 and 1 ; and $\omega$ represents the inertia weight.

$\omega(t)$ can be upgraded according to the following formula ${ }^{[37]}$.

$$
\omega(t)=\omega_{\max }-\left(\omega_{\max }-\omega_{\min }\right) \cdot t / t_{\max }
$$

where, $\omega_{\max }$ and $\omega_{\min }$ are the maximum and minimum values of inertia weight, and are usually assigned values of 1 and 0 ; and $t_{\max }$ is the number of iterations.

$P_{i}(t)$ and $P_{\mathrm{g}}(t)$ can be upgraded according to the following formulas:

$$
p_{i}(t)=\left\{\begin{array}{cc}
x_{i}(t+1), & \text { if fitness }\left(x_{i}(t+1)\right)<\text { fitness }\left(x_{i}(t)\right) \\
P_{i}(t), & \text { other wise }
\end{array}\right.
$$

The optimal position of the whole swarm at time $t$ is calculated from Equation (11):

$$
P_{\mathrm{g}}(t)=\min \left\{\text { fitness }\left(P_{1}(t)\right), \text { fitness }\left(P_{2}(t)\right), \cdots, \text { fitness }\left(P_{N}(t)\right)\right\}
$$

\section{Results and discussion}

The aim of model was to generate desired alternatives for crop area based on maximizing the net benefit per unit of irrigation water and given constraints. The model equations were solved using the method described in 2.2.4.

\subsection{Irrigation water-saving potential}

Irrigation water quantity is a key determinant of crop area optimization model. However, besides irrigation water, the irrigation water-saving potential in irrigation district can be used as irrigation water if engineering-type water-saving is considered.

The water-saving rate was represented as the relative proportion of water-saving irrigation area and effective irrigated area in this study. For the current situation, the effective irrigated area is $140349 \mathrm{hm}^{2}$, and the water-saving irrigation area is $58217 \mathrm{hm}^{2}$, therefore the water-saving rate was $41.48 \%$. The water use efficiency is 0.52 in this region. The current condition was defined as scenario $\mathrm{S}_{0}$. According to the water resources planning of Zhangye City (http://www.zhangye.gov.cn/), the water use efficiency should exceed 0.60 by 2020 . After the calculation in this paper, when the water-saving rate increased by $10 \%$ and $20 \%$, it would increase to 0.6 and 0.62 , which fulfills requirements of water resources planning. Therefore, the situations when water-saving rates increase $10 \%$ and $20 \%$ were defined as scenario $\mathrm{S}_{1}$ and scenario $\mathrm{S}_{2}$ respectively.

Assuming the effective irrigated area $140349 \mathrm{hm}^{2}$ is invariable, when the water-saving rate was assumed to increase $10 \%$, the increment of water-saving irrigation area would be $14035 \mathrm{hm}^{2}$. However, when relative proportions of the canal water-saving irrigation area and field water-saving irrigation area exhibit randomness which will lead to highly uncertain water-saving quantity, because the reduction of net irrigation quota of field water-saving irrigation was $1605 \mathrm{~m}^{3} / \mathrm{hm}^{2}$, while the reduction of net irrigation quota of canal water-saving irrigation was $1530 \mathrm{~m}^{3} / \mathrm{hm}^{2}$. For example, in case the increment area was all allocated to canal water-saving irrigation area, assuming the relative proportions between cannel leakage prevention and low pressure pipe transport is invariable, then the cannel leakage prevention area should be $42760 \mathrm{hm}^{2}$ and the low pressure pipe transport area should be $23273 \mathrm{hm}^{2}$. If the increment area was all allocated to field water-saving irrigation area, then the area of cannel leakage prevention and low pressure pipe transport should be the same as the area in $S_{0}$ scenario. The water-saving area of canal and field under different scenarios can be calculated (as shown in Table 2). 
Based on the area analysis above, the water-saving potential was calculated according to the Equations (1)-(5), under the current circumstance, gross irrigation quota is $13096 \mathrm{~m}^{3} / \mathrm{hm}^{2}$, when water-saving rate increases $10 \%$, it would drop to 10937 $11132 \mathrm{~m}^{3} / \mathrm{hm}^{2}$, meanwhile net irrigation quota would drop from $6810 \mathrm{~m}^{3} / \mathrm{hm}^{2}$ to $6650-6657 \mathrm{~m}^{3} / \mathrm{hm}^{2}$. Accordingly, water use efficiency would change from 0.520 to $0.598-0.608$. Similarly, when water-saving rate increases $20 \%$, it would drop to 10366 $10733 \mathrm{~m}^{3} / \mathrm{hm}^{2}$, meanwhile net irrigation quota would drop to $6489-6504 \mathrm{~m}^{3} / \mathrm{hm}^{2}$, accordingly, water use efficiency would rise to 0.606-0.626 (as shown in Table 3).

In order to solve the irrigation water-saving area in future, the maximum and minimum values of net water-saving quantity were calculated in order to mitigate the impact of uncertainty.

Table 2 Water-saving area under different water-saving scenarios

\begin{tabular}{|c|c|c|c|c|c|c|c|c|}
\hline \multirow{2}{*}{ Scenario } & \multirow{2}{*}{$\begin{array}{c}\text { Water-saving } \\
\text { rate } / \%\end{array}$} & \multirow{2}{*}{$\begin{array}{l}\text { Effective irrigated } \\
\text { area/hm }\end{array}$} & \multicolumn{2}{|c|}{ Canal water-saving irrigation area $/ \mathrm{hm}^{2}$} & \multicolumn{3}{|c|}{ Field water-saving irrigation area $/ \mathrm{hm}^{2}$} & \multirow{2}{*}{$\begin{array}{l}\text { Total } \\
/ \mathrm{hm}^{2}\end{array}$} \\
\hline & & & $\begin{array}{c}\text { Cannel leakage } \\
\text { prevention }\end{array}$ & $\begin{array}{l}\text { Low pressure pipe } \\
\text { transport }\end{array}$ & Drip irrigation & Spray irrigation & Other measures & \\
\hline $\mathrm{S}_{0}$ & 41.48 & 140349 & 33667 & 18328 & 6067 & 129 & 27 & 58217 \\
\hline $\mathrm{S}_{1}$ & 51.48 & 140349 & $33667-42760$ & $18328-23273$ & $6067-19747$ & $129-420$ & $27-87$ & 72252 \\
\hline $\mathrm{S}_{2}$ & 61.48 & 140349 & $33667-51840$ & $18328-28220$ & $6067-33433$ & $129-713$ & $27-147$ & 86287 \\
\hline
\end{tabular}

Table 3 Water-saving potential under different water-saving scenarios

\begin{tabular}{ccccc}
\hline Scenario & $\begin{array}{c}\text { Gross irrigation quota } \\
/ \mathrm{m}^{3} \cdot \mathrm{hm}^{-2}\end{array}$ & $\begin{array}{c}\text { Net irrigation quota } \\
/ \mathrm{m}^{3} \cdot \mathrm{hm}^{-2}\end{array}$ & Water use efficiency & $\begin{array}{c}\text { Net water-saving quantity } \\
/ \mathrm{million}^{-3} \mathrm{~m}^{-3}\end{array}$ \\
\hline $\mathrm{S}_{0}$ & 13096 & 6810 & 0.520 & $\begin{array}{c}\text { Gross water-saving quantity } \\
/ \mathrm{million}^{-3} \mathrm{~m}^{-3}\end{array}$ \\
$\mathrm{~S}_{1}$ & $10937-11132$ & $6650-6657$ & $0.598-0.608$ & $21.5-22.5$ \\
$\mathrm{~S}_{2}$ & $10366-10733$ & $6489-6504$ & $0.606-0.626$ & $43.0-45.1$ \\
\hline
\end{tabular}

Figure 3 shows the relationship between net water-saving quantity and relative proportions of canal water-saving irrigation area and field water-saving irrigation area. In case the increment area was all allocated to canal water-saving irrigation area, the net water-saving quantity would be 21.5 million $\mathrm{m}^{3}$. Otherwise, in a situation in which the increment area was all allocated to field water-saving irrigation area, the net water-saving quantity would be

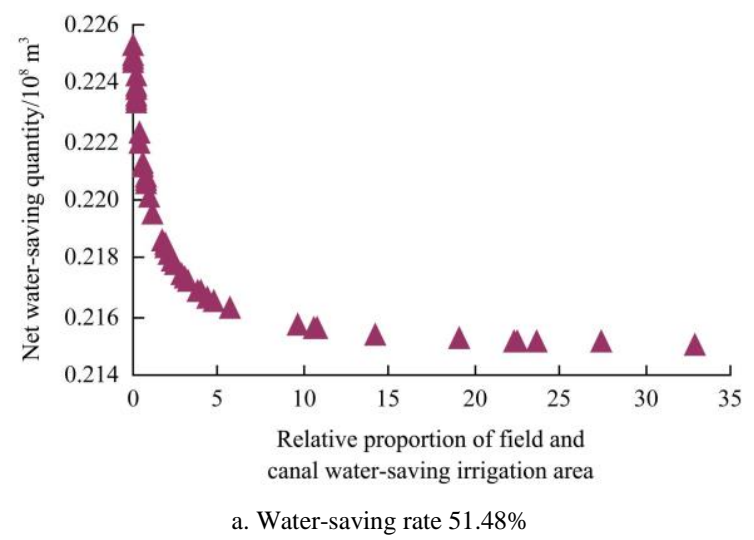

22.5 million $\mathrm{m}^{3}$. Namely, if water-saving rate increases by $10 \%$, the net water-saving quantity would increase by $21.5-22.5$ million $\mathrm{m}^{3}$, the gross water-saving quantity would increase by 275.7303.0 million $\mathrm{m}^{3}$. Similarly, if the water-saving rate increased by $20 \%$, the net water-saving quantity would increase by 43.0 45.1 million $\mathrm{m}^{3}$, the gross water-saving quantity would increase by 331.7-383.2 million $\mathrm{m}^{3}$.

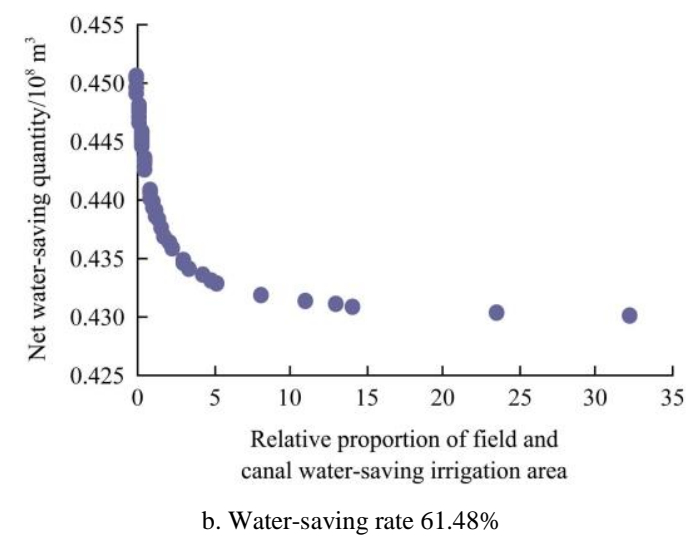

Figure 3 Net water-saving quantity under different water-saving rate

\subsection{Available irrigation water}

A development pattern of agricultural crop structure in the future was proposed by considering an agricultural cropping pattern optimization model under different probabilities of water level, and in conjunction with agricultural water saving potential in future. Figure 4 shows the available irrigation water when water-saving rate increases $10 \%$ and $20 \%$. In Heihe River basin, State Council of the People's Republic of China introduced a series of regulations about water reallocation of the Heihe River to recover ecological environment in the downstream area and relieve water contradiction in Heihe River basin. The plan of water reallocation of the Heihe River stipulates the water discharge of Zhengyixia station under different probabilities of water level, for example, when the probability of water level is $90 \%$, stream flow in Yingluoxia station is 1900 million $\mathrm{m}^{3}$, there must be 1320 million $\mathrm{m}^{3}$ discharge at Zhengyixia station. However, when the probability of water level is $10 \%$, stream flow in Yingluoxia Station is 1290 million $\mathrm{m}^{3}$, there must be 630 million $\mathrm{m}^{3}$ discharges at Zhengyixia station. Therefore, the available water for agriculture will become less in high flow year compared with the low flow year.

\subsection{Cropping pattern optimization}

According to various flow levels and agricultural water saving potential, 7 different crops and 10 scenarios of water availability were designed to analyze agricultural cropping patterns in future. Scenarios 1 and 2 are in very-low years, the water-saving rates are $51.48 \%$ and $61.48 \%$, respectively, and the available water volumes for agriculture are 1704 million $\mathrm{m}^{3}$ and 1772 million $\mathrm{m}^{3}$; scenarios 3 and 4 are in low flow years, the water-saving rates are $51.48 \%$ and $61.48 \%$, respectively, and the available water volumes for 
agriculture are 1761 million $\mathrm{m}^{3}$ and 1829 million $\mathrm{m}^{3}$; scenarios 5 and 6 are in normal flow years, the water-saving rates are $51.48 \%$ and $61.48 \%$ respectively, and the available water volumes for agriculture are 1722 million $\mathrm{m}^{3}$ and 1790 million $\mathrm{m}^{3}$; scenario 7 and 8 are in high flow years, the water-saving rates are $51.48 \%$ and

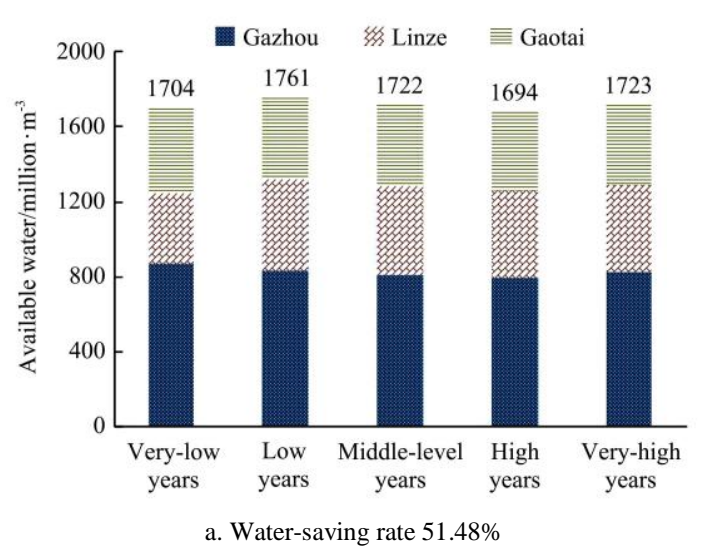

$61.48 \%$, respectively, and the available water volumes for agriculture are 1694 million $\mathrm{m}^{3}$ and 1762 million $\mathrm{m}^{3}$; and scenarios 9 and 10 are in very-high flow years, the water-saving rates are $51.48 \%$ and $61.48 \%$, respectively, and the available water for agriculture are 1723 million $\mathrm{m}^{3}$ and 1791 million $\mathrm{m}^{3}$.

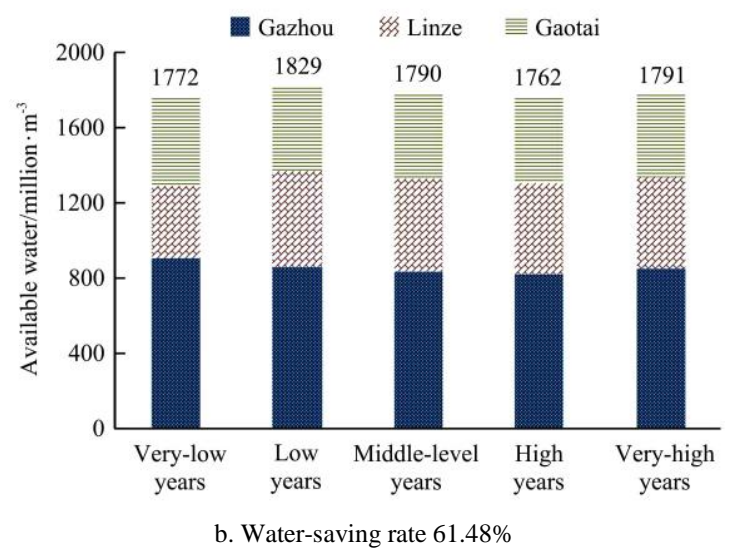

Figure 4 Available irrigation water under different water-saving rate

Figure 5 presents the optimized crop area patterns in different scenarios of Ganzhou, Linze and Gaotai County. In conjunction with available irrigation obtained from Figure 4, the total cultivated areas were different, because of the different available water under different scenarios.

The process of determining the optimal cropping pattern was operating at the level of irrigation district. In fact, optimal solutions of planting structure were related to various variables, such as irrigation quota and yield per hectare, which were different in different irrigation districts. Figure 5a gives the optimal cropping pattern under very low flow level. In Figure 5a, as water-saving rate increases under the same water level, the cultivable area of maize seed increases in Ganzhou, Linze and Gaotai county, while the vegetable and potato area is transferred to other 5 crops in Ganzhou county, the wheat and potato area is transferred to other 5 crops in Linze county, and the wheat area is transferred to other 6 crops in Gaotai county.

It can be found in Figure 5 and Table 4 that the cultivable area of maize seed and the optimal system benefit increases in Ganzhou, Linze and Gaotai county, while the total quantity of irrigation water increases. That means the optimal water and cultivated area allocation to maize seed is greater than water and cultivated area allocation to other crops. For the reason that compares with other crops, the irrigation quota of maize seed is smaller than maize, potato and vegetable in most irrigation districts and the unit price is higher than maize, wheat, potato and vegetable in most irrigation districts, so that the benefit per unit of water is higher than other crops.

Another relevant result is the fact that the major crops in Ganzhou, Linze and Gaotai county are similar, while the proportions of the main crops are different in these three counties. For example, the proportion of maize seed in Ganzhou, Linze and Gaotai County is about 77\%, 59\%, 40\% respectively. Except for maize seed, the cultivable area of maize area is the second largest in Ganzhou county, accounting for about $10 \%$ in different scenarios, and then is vegetable and wheat, accounting for about $7 \%$ and $5 \%$, respectively.

While the cultivable area of wheat is the second largest in Linze County, approaching $26 \%$ in different scenarios, and then is vegetable and maize, the proportions of them are nearly $9 \%$ and $6 \%$, respectively. However, the cultivable area of maize is the second largest in Gaotai County, accounting for approximately $23 \%$ in different scenarios, and then is vegetable and cotton; the proportions of them are nearly $14 \%$ and $12 \%$, respectively.

Comparing Figure $5 \mathrm{c}$ with Figure $5 \mathrm{e}$, it can be found that the total quantities of irrigation water are approximate under normal flow level and very-high flow level, however, the optimized crop area patterns showed some differences, for the available irrigation water allocation is different in irrigation districts.

The solutions obtained can not only provide an effective evaluation under present scenarios, but also reveal the associated economic implications. Different scenarios would result in varied system benefits. Table 4 gives the system benefits of the middle reaches of Heihe River basin under different scenarios. Results reveal that stream flow level is an important variable which can directly affect optimal system benefit.

Under the premise of maximum economic benefit per unit of irrigation water, optimal total benefit achieves 2.68 billion RMB, and the benefit of per unit of irrigation water is $2.703 \mathrm{RMB} / \mathrm{m}^{3}$ under low flow level, with the available irrigation water quantity being 1761 million $\mathrm{m}^{3}$ and the water-saving rate being $51.48 \%$, when the water-saving rate increases to $61.48 \%$, optimal total benefit would achieve 2.87 billion RMB, and benefit of per unit of irrigation water would be $2.731 \mathrm{RMB} / \mathrm{m}^{3}$.

It reveals under the same distribution of available irrigation water that as the quantity decreases, the system benefit and net benefit per unit of irrigation water would decrease for the reason of less water availability. For example, optimal total benefit achieves 2.54 billion RMB, and benefit of per unit of irrigation water is $2.699 \mathrm{RMB} / \mathrm{m}^{3}$ under high flow level, with available irrigation water quantity being 1694 million $\mathrm{m}^{3}$ and water-saving rate being $51.48 \%$, when the water-saving rate increases to $61.48 \%$, optimal total benefit would achieve 2.65 billion RMB, and benefit of per unit of irrigation water would be $2.716 \mathrm{RMB} / \mathrm{m}^{3}$.

The result shows the difference between system benefit and net benefit per unit of irrigation water, under the approximate available irrigation water quantity (Scenarios 5, 6, 9, 10). Because under very-high flow level, the allocation of available irrigation water is different from the allocation under normal flow level, there is more available irrigation water in some well-equipped irrigation districts, which lead to more benefit per unit of water compared with other irrigation districts. 

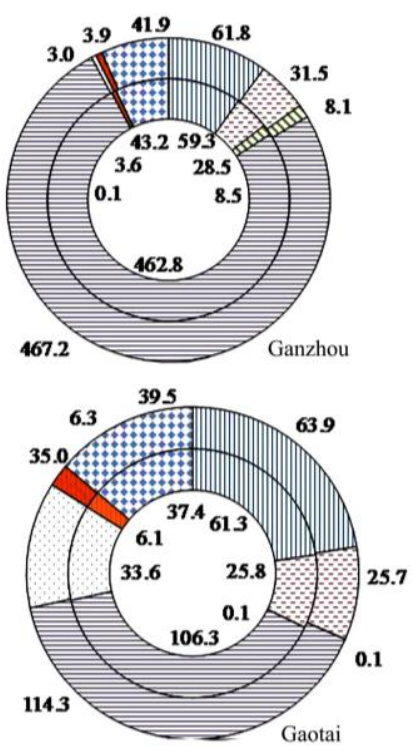

四 Maize
㐘 Wheat
Potato
目 Maize seed
$\square$ Cotton
$\square$ Oil crops
Vegetables

a. Very-low years
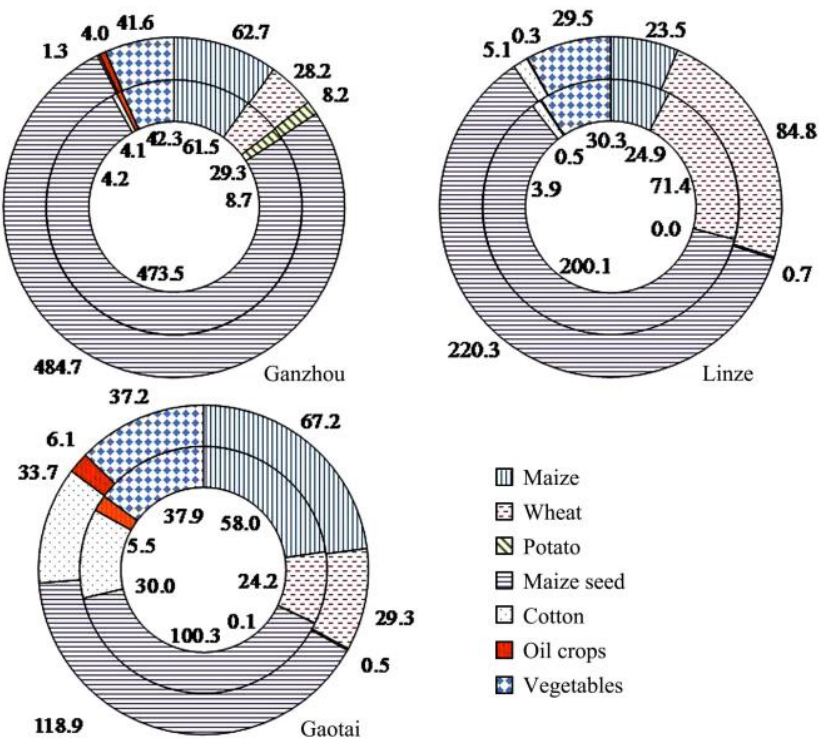

四 Maize

웅 Wheat

$\mathbb{Q}$ Potato

目 Maize seed

$\square$ Cotton

$\square$ Oil crops

Vegetables

c. Middle-level years
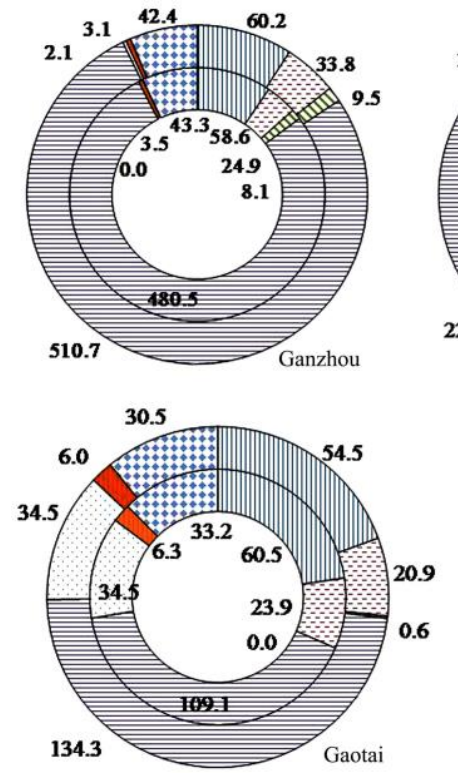

四 Maize

园 Whea

$\triangle$ Potato

目 Maize seed

$\square$ Cotton

$\square$ Oil crops

Vegetables

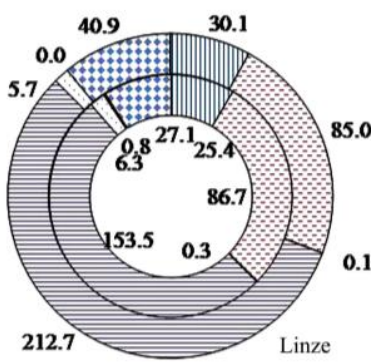

四 Maize

웅 Wheat

$\checkmark$ Potato

目 Maize seed

$\square$ Cotton

$\square$ Oil crops

Vegetables

b. Low years
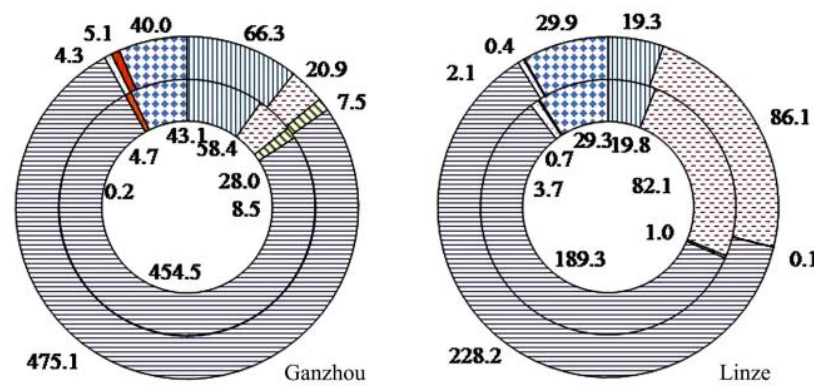

四 Maize

固 Wheat

$\triangle$ Potato

目 Maize seed

$\square$ Cotton

$\square$ Oil crops

国 Vegetables 
Table 4 Optimal system benefit under different water-saving scenarios

\begin{tabular}{|c|c|c|c|c|c|c|}
\hline Scenario & Flow level & $\begin{array}{l}\text { Water-saving } \\
\text { rate }\end{array}$ & $\begin{array}{l}\text { Water use } \\
\text { efficiency }\end{array}$ & $\begin{array}{c}\text { Available irrigation } \\
\text { water quantity/million } \mathrm{m}^{3}\end{array}$ & $\begin{array}{l}\text { net benefit per unit of irrigation } \\
\text { water/RMB } \cdot \mathrm{m}^{-3}\end{array}$ & $\begin{array}{l}\text { Optimal system benefit } \\
\text { /billion RMB }\end{array}$ \\
\hline 1 & \multirow{2}{*}{ Very-low } & $51.48 \%$ & 0.59 & 1704 & 2.682 & 2.61 \\
\hline 2 & & $61.48 \%$ & 0.61 & 1772 & 2.715 & 2.68 \\
\hline 3 & \multirow{2}{*}{ Low flow } & $51.48 \%$ & 0.59 & 1761 & 2.703 & 2.68 \\
\hline 4 & & $61.48 \%$ & 0.61 & 1829 & 2.731 & 2.87 \\
\hline 5 & \multirow{2}{*}{ Normal flow } & $51.48 \%$ & 0.59 & 1722 & 2.678 & 2.64 \\
\hline 6 & & $61.48 \%$ & 0.61 & 1790 & 2.730 & 2.71 \\
\hline 7 & \multirow{2}{*}{ High flow } & $51.48 \%$ & 0.59 & 1694 & 2.699 & 2.54 \\
\hline 8 & & $61.48 \%$ & 0.61 & 1762 & 2.716 & 2.65 \\
\hline 9 & \multirow{2}{*}{ Very-high } & $51.48 \%$ & 0.59 & 1723 & 2.727 & 2.63 \\
\hline 10 & & $61.48 \%$ & 0.61 & 1791 & 2.742 & 2.81 \\
\hline
\end{tabular}

\section{Conclusions}

The development pattern of agricultural crops structure in the future was proposed by considering an agriculture cropping pattern optimization model under different probabilities of water levels, and in conjunction with agricultural water-saving potential in future and was applied to Heihe River basin in Gansu Province, China.

This model is based on quantifying agricultural water-saving potential and determining the optimal structure which could obtain maximum agricultural net benefit per unit of irrigation water by allocating the limited water to 7 main crops. The main advantage of this model is that it can quantify the water-saving potential of irrigation area in future by calculating the maximum and minimum values of net water-saving quantity.

Under the premise of water-saving agricultural irrigation development, there is enormous water-saving potential in the middle reaches of Heihe River basin. Under the current circumstance the gross irrigation quota is $13096 \mathrm{~m}^{3} / \mathrm{hm}^{2}$, when the water-saving rate increases by $10 \%$, it would drop to 10937 $11132 \mathrm{~m}^{3} / \mathrm{hm}^{2}$, accordingly, the water use efficiency would change from 0.520 to $0.598-0.608$. As a result, there would be 275.7303.0 million $\mathrm{m}^{3}$ irrigation water to be saved. Similarly, when water-saving rate increases by $20 \%$, there would be 331.7 383.2 million $\mathrm{m}^{3}$ irrigation water to be saved.

Seven different crops and 10 scenarios of water availability have been designed to analyze the different agriculture cropping patterns in future according to various flow levels and agriculture water saving potential, aiming at maximizing the profitability of irrigation agriculture by incorporating a more efficient use of irrigation water through effective crop structure adjustment. It suggests that the optimal water and cultivated area allocation to maize seed is greater than to other crops. The irrigation quota of maize seed is smaller than maize, potato and vegetable in most irrigation districts and its unit price is higher than maize, wheat, potato and vegetable in most irrigation districts, so that the benefit per unit water is higher than other crops.

Under the premise of similar volume of irrigation water quantity available in different scenarios, results show the difference in system benefit and net benefit per unit of irrigation water, for the distribution of available irrigation water is diverse in different irrigation districts.

\section{Acknowledgments}

We acknowledge that this work was financially supported by the National Natural Science Fund in China (Grant No. 91425302,
91325201) and National Key Research and Development Program during the 13th Five-year Plan in China (Grant No. 2016YFC0401306).

\section{[References]}

[1] Niu G, Li Y P, Huang G H, Liu J, Fan Y R. Crop planning and water resource allocation for sustainable development of an irrigation region in China under multiple uncertainties. Agricultural Water Management, 2016; 166: 53-69.

[2] Rai R K, Singh V P, Upadhyay A. Planning and evaluation of irrigation projects. Academic Press, 2017.

[3] Su X L, Li J F, Singh V P. Optimal allocation of agricultural water resources based on virtual water subdivision in Shiyang River Basin. Water Resources Management, 2014; 28(8): 2243-2257.

[4] Dong Z Q, Pan Z H, Wang S, An P L, Zhang J T, Zhang J, et al Effective crop structure adjustment under climate change. Ecological Indicators, 2016; 69: 571-577.

[5] Asres S B. Evaluating and enhancing irrigation water management in the upper Blue Nile basin, Ethiopia: The case of Koga large scale irrigation scheme. Agricultural Water Management, 2016; 170: 26-35.

[6] Lei B, Liu Y, Xu D. Estimating theory and method of irrigation water-saving potential based on irrigation district scale. Transactions of the CSAE, 2011; 27(1): 10-14. (In Chinese)

[7] López-Mata E, Orengo-Valverde J J, Tarjuelo J M, Martinez-Romero A, Dominguez A. Development of a direct-solution algorithm for determining the optimal crop planning of farms using deficit irrigation. Agricultural Water Management, 2016; 171: 173-187.

[8] Zhang D, Guo P. Integrated agriculture water management optimization model for water saving potential analysis. Agricultural Water Management, 2016; 170: 5-19.

[9] Karimov A, Molden D, Khamzina T, Platonov A, Ivanov Y. A water accounting procedure to determine the water savings potential of the Fergana Valley. Agricultural water management, 2012; 108: 61-72

[10] Törnqvist R, Jarsjö J. Water savings through improved irrigation techniques: basin-scale quantification in semi-arid environments. Water Resources Management, 2012; 26(4): 949-962.

[11] Jägermeyr J, Gerten D, Heinke J, Schaphoff S, Matti K, Lucht W. Water savings potentials of irrigation systems: global simulation of processes and linkages. Hydrology and Earth System Sciences, 2015; 19(7): 3073-3091.

[12] Yan N N, Wu B F, Perry C, Zeng H W. Assessing potential water savings in agriculture on the Hai Basin plain, China. Agricultural Water Management, 2015; 154: 11-19.

[13] Gao H C, Wei T, Lou I, Yang Z F, Shen Z Y, Li Y X. Water saving effect on integrated water resource management. Resources, Conservation and Recycling, 2014; 93: 50-58.

[14] Damerau K, Patt A G, van Vliet O P R. Water saving potentials and possible trade-offs for future food and energy supply. Global Environmental Change, 2016; 39: 15-25.

[15] Zeng X T, Kang S Z, Li F S, Zhang L, Guo P. Fuzzy multi-objective linear programming applying to crop area planning. Agricultural Water Management, 2010; 98(1): 134-142.

[16] Srinivasa R K, Nagesh K D. Irrigation planning using genetic algorithms. Water Resources Management, 2004; 18(2): 163-176. 
[17] Galán-Martin A, Pozo C, Guillén-Gosálbez G, Vallejo A A, Esteller L J. Multi-stage linear programming model for optimizing cropping plan decisions under the new Common Agricultural Policy. Land Use Policy, 2015; 48: 515-524

[18] Garg N K, Dadhich S M. Integrated non-linear model for optimal cropping pattern and irrigation scheduling under deficit irrigation. Agricultural Water Management, 2014; 140: 1-13.

[19] Liu H, Wang X, Zhang X, Zhang L W, Li Y, Huang G H. Evaluation on the responses of maize (Zea mays L.) growth, yield and water use efficiency to drip irrigation water under mulch condition in the Hetao irrigation District of China. Agricultural Water Management, 2017; 179: 144-157.

[20] Singh A, Panda S N. Development and application of an optimization model for the maximization of net agricultural return. Agricultural Water Management, 2012; 115: 267-275.

[21] Pant M, Thangaraj R, Rani D, Abraham A, Srivastava D K. Estimation of optimal crop plan using nature inspired metaheuristics. World Journal of Modeling and Simulation, 2010; 6(2): 97-109.

[22] Sarker R, Ray T. An improved evolutionary algorithm for solving multi-objective crop planning models. Computers and Electronics in Agriculture, 2009; 68(2): 191-199.

[23] Márquez A L, Baños R, Gil C, Montoya M G, Manzano-Agugliaro F, Montoya F G. Multi-objective crop planning using pareto-based evolutionary algorithms. Agricultural Economics, 2011; 42(6): 649-656.

[24] Prisenk J, Turk J. A multi-goal mathematical approach for the optimization of crop planning on organic farms: a Slovenian case study. Pakistan Journal of Agricultural Sciences, 2015; 52(4): 971-979.

[25] Srivastava P, Singh R M. Optimization of cropping pattern in a canal command area using fuzzy programming approach. Water Resources Management, 2015; 29(12): 4481-4500.

[26] Sharma D K, Jana R K. Fuzzy goal programming based genetic algorithm approach to nutrient management for rice crop planning. International Journal of Production Economics, 2009; 121(1): 224-232.

[27] Lu H W, Huang G H, He L. Development of an interval-valued fuzzy linear-programming method based on infinite $\alpha$-cuts for water resources management. Environmental Modelling \& Software, 2010; 25(3):
354-361.

[28] Yang G Q, Guo P, Huo L J, Ren C F. Optimization of the irrigation water resources for Shijin irrigation district in north China. Agricultural Water Management, 2015; 158: 82-98.

[29] Xie Y L, Huang G H, Li W, Li J B, Li Y F. An inexact two-stage stochastic programming model for water resources management in Nansihu Lake Basin, China. Journal of Environmental Management, 2013; 127: 188-205.

[30] Li M, Guo P. A coupled random fuzzy two-stage programming model for crop area optimization-A case study of the middle Heihe River basin, China. Agricultural Water Management, 2015; 155: 53-66.

[31] Stoyan S J, Kwon R H. A two-stage stochastic mixed-integer programming approach to the index tracking problem. Optimization and Engineering, 2010; 11(2): 247-275.

[32] Cid-Garcia N M, Bravo-Lozano A G, Rios-Solis Y A. A crop planning and real-time irrigation method based on site-specific management zones and linear programming. Computers and Electronics in Agriculture, 2014 107: 20-28.

[33] Kennedy J. Particle swarm optimization. Encyclopedia of Machine Learning. Springer US, 2011

[34] Su X L, Singh V P, Niu J P, Hao L N. Spatiotemporal trends of aridity index in Shiyang River basin of northwest China. Stochastic Environmental Research and Risk Assessment, 2015; 29(6): 1571-1582.

[35] Li X L, Tong L, Niu J, Kang S Z, Du T S, Li S E, et al. Spatio-tempora distribution of irrigation water productivity and its driving factors for cereal crops in Hexi Corridor, Northwest China. Agricultural Water Management, 2017; 179: 55-63.

[36] Tong F F, Guo P. Simulation and optimization for crop water allocation based on crop water production functions and climate factor under uncertainty. Applied Mathematical Modeling, 2013; 37(14): 7708-7716.

[37] Clerc M, Kennedy J. The particle swarm-explosion, stability, and convergence in a multidimensional complex space. IEEE Transactions on Evolutionary Computation, 2002; 6(1): 58-73.

[38] Zhao M J, Jiang X H, Yao W Y, Liu J, Zhao Y, Dong G T. Analysis of dominant factors of affecting the released water amount of Zhengyixia section of Heihe River. Yellow River, 2016; 38(1): 56-59. (in Chinese) 